ISSN 2414-1143

Научный альманах стран Причерноморья. 2018. Том 15. № 3

DOI 10.23947/2414-1143-2018-15-3-30-36

UDC $316+796.5$

\title{
SOCIALOGICAL MEASURE OF ORGANIZED CULTURE DISPROPORTION IN MEDICAL TOURISM SYSTEM
}

\author{
(C) Viktor A. Bakhtin, Larisa A. Minasyan \\ Don State Technical University, Rostov-on-Don, Russian Federation \\ bakhtinvictor@icloud.com
}

The article examines the content of "medical tourism" concept. The necessity of terminological system development is underlined that focuses attention to some questions and their solution supposes attraction of tourism industry specialists because of specificity linked to the overlap of tourism industry and medicine activity. It is shown that the solution of social roles distribution of medical and tourist organizations in medical tourism, efforts consolidation of both categories employees must be preceded by classification of main and background institutional factors. The classification of institutional factors for different types of medical tourism is considered. The methods of sociometric measuring of disproportions of organized culture of medical establishment linked to the binarity of its components are offered. Positive results of an experiment demand further studying of the research prospect which consists in the need of search of features of doctors' professional education. The subject of their professional activity is humanization, humanitarization and crosscultural communication. Within the considered problems the need of harmonious system of medical tourism creation in the country's regions is proved. The cultural and educational space of medical school has to be followed by the need of the addition of education content by means of a wide polycultural context of medical tourism issues, training in professional communication with people, preparation of a doctor widely formed in moral and professional plan. The creation of the optimum sociocultural bringing-up environment promoting self-development and creative self-realization of personality of the future doctor in the field of health care will become the main idea of medical tourism as it is emphasized in the research.

Key words: medical tourism, social roles, classification, institutional factors, components` binarity

\section{[В.А. Бахтин, Л.А. Минасян Социологическое измерение диспропорций организационной куль- туры в системе медицинского туризма]}

В статье рассматривается содержание понятия «медицинский туризм». Подчеркивается необходимость понятийного расширения терминосистемы, что направляет внимание на ряд вопросов, решение которых предполагает привлечение специалистов туристской отрасли, так как возникает специфика, связанная с пересечением сфер деятельности туристской индустрии и медицины. Показано, что решению вопроса распределения социальных ролей медицинских и туристских организаций в развитии медицинского туризма, консолидации усилий работников обеих категорий должна предшествовать работа по классификации основных и фоновых институциональных факторов. Рассмотрена классификация институциональных фракторов для различных видов медицинского туризма. Предложены методы социометрического измерения диспропорций организационной культуры медицинского учреждения, связанных с бинарностью его составляющих. Положительные итоги эксперимента требуют дальнейшего изучения перспективы исследования, которая заключается в необходимости поиска особенностей профессионального образования врачей, предметом профессиональной деятельности которых выступает гуманизация, гуманитаризация и межкультурная коммуникация. В рамках рассматриваемых проблем обоснована необходимость создания в регионах страны стройной системы медицинского туризма. Культурно-образовательное пространство медицинского вуза должно сопровождаться необходимостью дополнения содержания образования посредством введения широкого поликультурного контекста проблематики медицинского туризма, обучению профессиональному общению с людьми, подготовкой широко образованного в нравственном и профессиональном плане врача. Основной идеей медицинского туризма, как подчеркивается в исследовании, станет создание оптимальной социокультурной воспитывающей среды, способствующей саморазвитию и творческой самореализации личности будущего врача в области здравоохранения.

Ключевые слова: медицинский туризм, социальные роли, классификация, институциональные факторы, бинарность составляющих. 
Viktor A. Bakhtin - postgraduate student. Don State Technical University. Rostov-on-Don, Russian Federation.

Бахтин Виктор Александрович - аспирант. Донской государственный технический университет. е. Ростов-на-Дону, Россия.

Larisa A. Minasyan - PhD of philosophy, professor, dean of the faculty of Service and Tourism. Don State Technical University. Rostov-on-Don, Russian Federation.

Минасян Лариса Артаваздовна - доктор философрских наук, профрессор, декан фракультета Сервис и туризм. Донской государственный технический университет. г. Ростов-на-Дону, Россия.

Concern for the health, increasing human vitality have become an integral part of the modern value system. Article 41 of the Constitution of the Russian Federation establishes the right of every citizen to health protection and medical care [5]. The Federal Law of the Russian Federation of November 21, 2011 N 323-FZ "On the basis of the protection of public health in the Russian Federation" determines the sources of financial support in the field of health protection: "the funds of the federal budget, budgets of the constituent entities of the Russian Federation, local budgets, funds of compulsory medical insurance, funds of organizations and citizens, funds received from individuals and legal entities, including donations, and other sources not prohibited by the legislation of the Russian Federation" [ 10, Article 82]. Thus, it can be argued that the health care system covers the entire territory of the country - from large metropolitan areas to rural areas. This is enshrined in the section of the law, where it is noted that the powers of the federal bodies of state power in the field of health protection include "conducting a unified state policy in the field of health care, developing and implementing programs for the formation of a healthy lifestyle and other programs in the field of health measures, the implementation of measures for the development of health care "[10, Art.16] and "the establishment of requirements for the placement of medical organizations of the state health care system and the municipal health system, and other health infrastructure based on the needs of the population "(emphasized by V.B., L.M.).

Of great importance is the "coordination of activities in the field of health protection of federal executive authorities, executive authorities of the constituent entities of the Russian Federation, local governments, parties of the state health care system, the municipal health care system and the private health care system" [10, p. 16.1, p.11]. The authorized federal government body is required to establish a procedure for the implementation of medical activity on the principles of public-private partnership in the field of health protection. It is important to emphasize that the law establishes the right of the patient to choose a medical organization and a doctor [10, p. 10].

The uniqueness of any medical institution or medical specialist, rightly extending beyond a specific municipality, becomes a factor for attracting people to a given locality in search of high-quality medical care from other regions of the country and also from abroad. One can cite a sufficient number of unique examples in domestic medical practice. This is MNTK "Eye Microsurgery named after academician S.N. Fedorov", Scientific Center of Cardiovascular Surgery named. A.N. Bakulev and the Center for Thoracic Surgery in the city of Krasnodar and others. And, therefore, it is legitimate to talk about medical tourism and raise the question of technologies and methods for its development. Patients in most cases come with their relatives, who need to be accommodated, preferably in proximity to the medical institution. Meanwhile, the problem of the development of medical tourism remains behind the scenes of all acts of title, regional development strategies, etc. 
For example, the city of Rostov-on-Don is the largest metropolis in the country, the capital of the Southern Federal District. The city attracts those who wish to receive qualified medical care from various localities of the Rostov region (from cities to villages and farms). Meanwhile, the term 'medical tourism' is largely used for cases when a person travels abroad, for example, to Germany or Israel. The legality of such a use of the term "medical tourism" is not in doubt. However, it is necessary to point out the expansion of its functioning space. What is meant by medical tourism and where does the line lie between it and medical, health or sports and health tourism?

In the work of G.Y. Shchekin gives the following definitions: "Medical tourism is a specially organized trip outside the country (region of residence) with the aim of obtaining the necessary medical treatment (clinical intervention)" [11]. It seems that in this definition it is necessary to put the expression "region of residence" out of the brackets, narrowing it to the expression "place of residence". Because traveling to get treatment, for example, from the village of Bokovskaya in Rostov-on-Don (within the same region - the Rostov region) cannot according to this definition be considered as medical tourism, although the distance between these settlements is over $340 \mathrm{~km}$. At the same time, the organization of pupils in the city of Taganrog, among many of whose attractions is the house of Anton Pavlovich Chekhov, is interpreted as educational tourism. It seems that the clarification in the definition is important for the penetration of the term "medical tourism" into management decisions.

For example, let us refer again to the city of Rostov-on-Don. In such documents as the "Main Directions of the Strategic Plan for Socio-Economic Development of the City of Rostov-on-Don for the Period up to 2025" (hereinafter, Strategy) [8] and the "Master Plan for the Development of the City of Rostov- on-don (2007-2025) (hereinafter, General Plan) [1] attention is paid to the issues of preserving and strengthening the health of the population through the sustainable development of the city's health system. The Strategy defines the development and implementation of the municipal target program "Rostov-on-Don - the territory of health and demographic well-being" as the key one [8, p.40; 5]. The total funding of the program will be more than 2.7 billion rubles, of which over 750 million will be allocated from the regional budget and about 2 billion rubles from the city budget. According to these concepts, a set of measures is envisaged in the orientation of the industry to "prevent disease", which corresponds to global trends; development of the 3-level structure of the ambulatory-polyclinic network; construction of hospitals, clinics.

The number of doctors per 10,000 population should reach 96 by 2025, paramedical personnel -122 , provision of hospital beds -130 . It is important that the urban planning policy of locating a stationary hospital network in the city provides for the formation of two levels: level (within the planning districts, each of which includes several administrative districts), allowing to ensure fast delivery of the patient in accordance with the standards (standard magnetizations passed 10 beds per 1000 people).; the urban level, to which the hospital network belongs, is not rigidly tied to the district (federal, departmental, regional, specialized) and provides services not only to the residents of Rostov-on-Don, but also to the people living in it for this type service. The security standard is 2.5 beds per 1000 inhabitants. Thus, medical tourism is initially embedded in the accepted indicators of both Strategies and the General Plan.

Meanwhile, in the same Strategy spelled out the specialization of the city in the tourist market, namely, the promotion of business tourism, which is recognized as one of the strategically significant areas of diversification of the local economy [3, p. 20]. Medical tourism is not considered. A credit to G.Y. Shchekina [11] undoubtedly is that he actualized the need for conceptualization of medical tourism, took certain steps in developing the principles of his organization, suggested recommendations for optimizing the process of its institutionalization in Russia. It is desirable that this was informed at the executive level. 
We are provided with a very convincingly different definition of medical tourism given in the scientific literature. "Medical tourism is a part of tourist activity, which assumes as the main motive of the trip that tourists receive a complex of treatment and diagnostic, rehabilitation, preventive and recreational services provided in areas other than their permanent residence, natural, material and human resources in order to prevent diseases or rehabilitate the treatment of various pathologies "[11].

As we see it, the adoption of the term "medical tourism" implies a focus on the word "tourism", and, therefore, a number of issues need to be addressed, the solution of which is connected with the involvement of specialists from the tourism industry, as there is a specific intersection of the tourist industry and medicine. According to the share and composition of medical services, according to the list of medical indications, health resort treatment and rehabilitation should also be attributed to medical tourism. In work [9, $\mathrm{p}$. $260]$ the characteristic of types of health tourism is given. If there is a list of medical indications, we are talking about medical tourism, in the case of their absence - about health.

Medical tourism includes two types, differing in the objectives of the consumer and the characteristics of medical services in the composition of the tourist product. Thus, sanatorium-resort treatment and rehabilitation implies partial availability of medical services as part of the tourism product. Here the main focus is on rehabilitative or prophylactic treatment. Naturally, such services are rendered on the basis of medical institutions of a sanatorium and rehabilitation and rehabilitation profile. The second type is treatment, when medical services constitute the main part of the tourist product and are carried out on the basis of specialized medical institutions.

As noted above, the number of social facilities providing recreational, treatment and rehabilitation and medical services is quite large. Their territorial localization depends on the natural, historical, cultural and socio-economic characteristics of the teritories. The Rostov Region is not part of the resort zones that have traditionally proven themselves on the territory of the Russian Federation. Meanwhile, as noted in [6], in the region, included in Rostov-on-Don, there are specialized medical enterprises and medical institutions that provide sanatorium-preventive treatment. Medical tourism to one degree or another is always associated with various forms of recreation. In this connection, serious problems arise, the main one of which is associated with a possible disproportion in the distribution and consumption of medical and leisure services.

However, depending on the type of medical tourism, different approaches are needed in the selection of recreational services. On the one hand, the disproportion in the distribution and consumption of medical and leisure services should be minimized, on the other hand, recognizing the binary nature of the social function of medical tourism as a therapeutic, recreational and leisure activity, should be wary of attempts to expand the scope of leisure services that are not always beneficial to health. As a result, it is important to address the issue of the distribution of the social roles of medical and tourist organizations in the development of medical tourism.

Specialists of the tourism industry, as a rule, do not have proper medical qualifications, medical workers, in turn, are not able to provide a complex of service measures for their clients. A conscious consolidation of the efforts of both categories of workers is required. The achievement of such consolidation should be preceded by the work on the classification of the main and background institutional factors. The main institutional factors include: 1. Factors of the proposal of medical services; 2. Traditions of treatment; 3 . Factors of awareness about the medical services market; 4 . Factors of differentiation of the medical services market by regions and separately by settlements of a particular region; 5 . Factors of state preferences. Since in the context of such a phenomenon as medical tourism, it is primarily a matter of client health, the complex of main institutional factors primarily includes the level of medical services. 
If we are talking about this type of medical tourism as treatment, then it is the abovementioned factors that make up the leading role in the choice of a medical institution by the client. The service component plays an important, but still second-degree role in the choice of a particular medical institution, it forms groups of background factors. Here, the main background factor is the assistance of the institution in the placement of persons accompanying the client, providing them with places in hotels.

The main factors should not be added: climatic conditions; physical methods (laser therapy, magnetic therapy, aromatherapy, ozone therapy, etc.); balanced diet; recreation facilities are included in the group of background factors.

Researchers [2, p. 86], following the authors of [3], concentrate on the concept of "recreation" (from Lat. - recreation - recovery), including in its content: any game, entertainment, etc., used for restoration of physical and mental strength;

- a segment of the leisure industry related to public participation in outdoor activities;

- restructuring of the organism and human populations, providing the possibility of active activities under different conditions, nature and environmental changes;

- civilized recreation provided by various types of disease prevention in stationary conditions, sightseeing and tourist activities, as well as in the process of physical exercise.

Thus, the concept of recreation extends to the leisure and recreational component of the functioning of a sanatorium institution. In this case, the service component assumes its importance.

General cultural stereotypes of clients, as well as age and gender ones should also be attributed as background factors; [4].

For the studied types of medical tourism, the task of a sociometric measurement of the disproportions of the organizational culture of the institution associated with the binary nature of its components arises. To accomplish this task, it is supposed to use the following methods of sociology using the ordinal (rank) scale:

1. Content analysis. Analysis of special literature and Internet communications.

2. Questionnaire. Telephone survey of residents of the region (cities and district centers) on the intentions to purchase medical tourism services in specific centers in the region (random sample).

3. Case study. The application of the case study method in studying the problems of medical tourism allows finding out the personal reasons for the different attitudes towards medical tourism services among consumers. In this area, this method is especially useful, since it not only detects personal attitudes, but also makes it possible to fill the deficit of other sociological information. Factors a) of successful medical tourism (recovery and good service) and b) negative results of medical tours (deterioration, financial losses) were analyzed.

4. Focus group. This method was used to find out the expert opinion, consider the details and formulate a collective conclusion. The research is supposed to be carried out among the patients of the sanatoriums of Rostov-on-Don: the sanatoriums "Nadezhda", "Sputnik LLC DOC", "Donagrokurort SKH of North Kazakhstan oblast", "Don health resort”, Rostov sanatorium, "Osher, pension for elderly, Gamma, health center, TEMP - health and cultural center of CJSC Yuzhte-hmontazh, etc. It should be noted that the clients of these institutions are not only Rostovites, but also residents of the Rostov region, Krasnodar region and other parts of Russia.

Achieving the quality of sociological empirical information with subsequent conclusions and recommendations is expected to be obtained with repeated measurements. Positive results of the experiment require further study of the perspectives of research, which is the need to find the features of the professional education of doctors, whose subject of professional activity is humanization, humanitarization and intercultural communication. 


\section{Лuтература}

1. Генеральный план развития города Ростова-на-Дону (2007-2025 годы). Приложение 2 к решению Думы № 251 от 24.024.2007 г. URL: http://www.rostovgorod.ru/upload/uf/ 827/8277b02cbf76d1141d5fb916993d6e6b.pdf (дата обращения 26 марта 2017 года).

2. Витинев А.М., Журавлева Л.Б. Курортное дело: Учебное пособие. М.: КНОРУС, 2006. $528 \mathrm{c}$.

3. Зорин И.В, Квартальнов В.А. Энциклопедия туризма: справочник. М.: Финансы и статистика, 2000. 368 с.

4. Казначеев Д.И. Социальные диспропорции оказания медицинских и немедицинских услуг на курортах России: на материалах курорта Пятигорск: Автореф. дис. ... канд. социол. наук. Ростов-на-Дону, 2005. 23 с.

5. Конституция Российской Федерации. URL: http://www.consultant.ru/ document/cons_doc_LAW_28399/ (дата обращения: 25.03.2017).

6. Минасян Л.А. Табадзе Г.С. Стратегии развития оздоровительного туризма (на примере города Ростова-на-Дону) // Современный туризм в лечебной и здравоохранительной деятельности. Волгоград: ВолгГМУ, 2016. С. 64-70.

7. Муниципальная программа «Развитие здравоохранения в Ростове-на-Дону». URL: http://rostov-gorod.info/(дата обращения 26 марта 2017 г.).

8. Основные направления стратегического плана социально-экономического развития города Ростова-на-Дону на период до 2025 года. URL: http://www.rostovgorod.ru/filebase/file_10514_0.doc (дата обращения 26 марта 2017 г.).

9. Туризм, технологии, экономика, управление: в 2 ч. / под общей ред. Г.А. Карповой, Л.В. Хоревой. Ч. 1. СПб.: СПбГЭУ, 2014. 276 с.

10. Федеральный закон Российской Федерации от 21 ноября 2011 г. N 323-Ф3 «Об основах охраны здоровья граждан в Российской Федерации». URL: http://www.consultant.ru/document/cons_doc_LAW_121895/ (дата обращения: 25. 03. 2017).

11. Щекин Г.Ю. Концептуализация феномена медицинского туризма в социологии медицины: Автореф. дис. ... д-ра социол. наук. Волгоград, 2013. 50 с.

\section{References}

1. Generalnyj plan razvitiya goroda Rostova-na-Donu (2007-2025).Prilozhenie $2 \mathrm{k}$ resheniyu Dumy №251 ot 24.24.2007. Retrieved from: http://www.rostovgorod.ru/upload/uf/ 827/8277b02cbf76d1141d5fb916993d6e6b.pdf (in Russian)

2. Vitinev A.M., Zhuravleva L.B. Kurortnoe delo: Uchebnoe posobie. M.: KNORUS, 2006. 528 p. (in Russian)

3. Zorin I.V, Kvartal'nov V.A. Entsiklopediya turizma: spravochnik. M.: Finansy i statistika, 2000. 368 p. (in Russian)

4. Kaznacheev D.I. Sotsialnye disproportsii okazaniya meditsinskih i nemeditsinskih uslug na kurortah Rossii: na materialah kurorta Pyatigorsk: Avtoref. dis. ... kand. sotsiol. nauk. Rostov-na-Donu, 2005. 23 p. (in Russian)

5. Konstitutsiya Rossijskoj Federatsii. Retrieved from: http://www.consultant.ru/ document/cons_doc_LAW_28399/(in Russian) 
6. Minasyan L.A. Tabadze G.S. Strategii razvitiya ozdorovitelnogo turizma (na prime-re goroda Rostova-na-Donu) // Sovremennyj turizm v lechebnoj i zdravoohranitel-noj deyatelnosti. Volgograd: VolgGMU, 2016. pp. 64-70. (in Russian)

7. Munitsipalnaya programma «Razvitie zdravoohraneniya v Rostove-na-Donu». Retrieved from: http://rostov-gorod.info/. (in Russian)

8. Osnovnye napravleniya strategicheskogo plana sotsialno-ekonomicheskogo razvitiya goroda Rostova-na-Donu na period do 2025. Retrieved from: http://www.rostovgorod.ru/filebase/file_10514_0.doc (in Russian)

9. Turizm, tekhnologii, ekonomika, upravlenie: $\vee 2$ ch. / pod obshchej red. G.A. Karpovoj, L.V. Horevoj. CH.1. SPb.: SPbGEU, 2014. 276 p. (in Russian)

10. Federalnyj zakon Rossijskoj Federatsii ot 21 noyabrya 2011. N 323-FZ «Ob osnovah ohrany zdorov'ya grazhdan $v$ Rossijskoj Federatsii». Retrieved from: http://www.consultant.ru/document/cons_doc_LAW_121895. (in Russian)

11. Shchekin G.YU. Kontseptualizatsiya fenomena meditsinskogo turizma $v$ sotsiologii meditsiny: Avtoref. dis. ... d-ra sotsiol. nauk. Volgograd, 2013. 50 p. (in Russian)

July 28, 2018 